\title{
Increasing Students' Speaking Achievement Through Animation Movie
}

\author{
Dian Shafwati \\ Universitas Lampung \\ Lampung, Indonesia \\ dianshafwati@fkip.unila.ac.id
}

\author{
Novita Nurdiana \\ Universitas Lampung \\ Lampung, Indonesia \\ novita.nurdiana@fkip.unila.ac.id
}

\author{
Gita Hilmi Prakoso \\ Universitas Lampung \\ Lampung, Indonesia \\ gitahilmi@gmail.com
}

\begin{abstract}
The purpose of this research is to find out whether or not there is increasing in students' speaking achievement after being taught through animation movies. 28 students who are taking Pre-Intermediate Speaking Class were involved in this research. It was quantitative research in which pre-test and post-test designs were performed. The result showed that there was increasing in students' speaking achievement after being taught by using animation movies. Therefore, it can be concluded that using animation movies is beneficial for students in Casey of speaking.
\end{abstract}

Keywords-animation movie, character building, impacts

\section{BACKGROUND}

In learning English, speaking ability is very important. to master. But, based on the observations and knowledge of the researcher as a lecturer in the speaking subject at FKIP, University of Lampung, it shows that in general, the students' speaking ability is not satisfactory. Most students still find obstacles in speaking English properly and correctly. This is also supported by research conducted by Nizzu (2015) which found that some English learners were not able to communicate orally well [1]. These obstacles include lack of vocabulary, low motivation, accuracy, and fluency in speaking. These constraints are caused by several factors. One of them is the use of inappropriate learning media.

Animated films are one of the effective media in teaching English [2-4]; Many researchers found the effectiveness of using animated films in teaching English. However, most of the researchers focus more on research on improving writing skills than speaking and the effectiveness of using animated films has never been linked to character building. Even though teaching about character building is very important, especially in a situation like today where learning is required to be carried out online because of the COVID-19 pandemic. Character building is certainly an aspect that should not be forgotten even though learning cannot be held faceto-face. Therefore, researchers are motivated to study the use of animated films as a learning medium to improve English speaking and development skills. student character.

\section{THEORY}

\section{A. Theory of Speaking}

Various definitions of speaking are stated by several experts. According to Hornby (1995: 826), speaking skills are abilities that function to express ideas, feelings, thoughts, and needs orally [5]. The main objective of teaching speaking skills is oral fluency; the ability to express oneself clearly; reasonable, accurate, and without undue doubt. In short, it can be said that the ability to speak is a complex ability to use language to express oneself in ordinary voices.

From several theories about speaking skills, it can be concluded that speaking is a complex and productive skill, namely the ability to use language orally through using sound to present information and generate ideas. Speaking ability is a set of abilities to express ideas, feelings, thoughts, adequately, and accurately. To speak well, learners need to practice their English. Many efforts can be made to improve speaking skills such as conducting dialogues, presenting oral presentations, group discussions, debates, and playing games.

The main purpose of speaking is to communicate. This is following the theory which states that speaking skills are abilities that function to express ideas, feelings, thoughts, and needs orally [5].

\section{B. Character Building}

Character is a way of thinking and behaving that characterizes each individual to live and work together, both within the family, community, nation, and state. Individuals with good character are individuals who can make decisions and are ready to account for every consequence of the decisions they make.

\section{Audio-Visual Media}

According to Sudjana and Rivai (2011), audiovisual media are materials that contain messages that 
can stimulate the thoughts, feelings, concerns, and willingness of students, so that the teaching and learning process occurs [6]. Meanwhile, according to Sanaky (2009), audio-visual media is a set of tools that can project images and sounds [7]. Tools - tools that include audio-visual media for example television, video VCD, sound slides, and films. Rinanto (1982) states that audio-visual media is a media consisting of visual media that is synchronized with audio media, which is very possible to establish two-way communication between teachers and students in the teaching and learning process [8].

Related to audio-visual media, researchers use animated films because the development of animated films is so fast and very interesting and animation is a technique in making audio-visual works based on timing in pictures.

\section{Animated Movies}

According to Darojah (2011), animated film media is audio-visual media in the form of a series of inanimate images that are sequentially on the frame and projected mechanically electronically so that they appear alive on the screen [9]. According to Rahayu and Kristiyantoro (2011) because it is considered interesting the use of animated films in the learning process can improve the quality of the process and learning outcomes [10]. Because this animated film media can attract students' attention, students will more easily understand the information conveyed because many senses are involved, especially the ears and eyes that are used to absorb information. Kurnati, Husna, and Ernati explained that animated films are interesting and effective media used to teach vocabulary, able to increase children's enthusiasm for learning pronunciation, helping children to understand and remember words better.

\section{METHODOLOGY}

\section{A. Research Design}

This study was conducted to determine the students' speaking ability (speaking) before and after using the media in the form of animated films and also to determine the effect of using animated films on English speaking skills. This type of research is a quasiexperimental research with one group pretest-posttest design. This study does not use a comparison class but has used an initial test so that the magnitude of the effect can be known with certainty. In addition, researchers also want to know the extent of the influence of the use of animated film media on student character building (character building). Related to this, the researcher will conduct interviews for data collection.

The procedure started from giving an initial test to students and then giving treatment in this case, namely learning using animation movies and ending with a final test. The tests given between the initial and final tests are in the form of and will be compared through the final score of each test.

$$
T_{1} \times T_{2}
$$

$\mathrm{T} 1$ submitted to the initial test before being given treatment using animated films and $\mathrm{T} 2$ submitted to the final test after being given treatment, namely the use of animated films. $X$ refers to treatment given using animated film researchers to improve the fluency of their [11].

\section{B. Research Subjects and Research Locations}

The subjects of this study were undergraduate students of the English Language Education Study Program, FKIP University of Lampung. One class consisted of 24 students who took pre-intermediate speaking courses.

\section{Research Instruments}

\section{- $\quad$ Speaking Test}

To obtain data, each student was given a speaking test before and after the learning process to determine the development of students' abilities before and after being given treatment using animated films.

\section{- Interview}

Interviews were conducted to determine the effect of using animated films on student character development. In this case, students are given several questions related to character building and learning to use animated films.

\section{Data Analysis Procedure}

In analyzing research study data, there are several stages carried out, namely:

1. Students' speaking test results are assessed based on the correct and appropriate speaking test answers used for the initial and final tests.

2. Student score data is processed using the SPSS application by first inputting student grade data into Ms. excel.

3. The results of the interviews were analyzed by describing students' opinions regarding learning using recorded animated films.

\section{E. Measurable Performance Indicators}

After collecting data, this research is considered accomplished if it finds out how the effect of animated films on students' speaking skills is by knowing whether there is an increase in students' speaking skills after using animated films. The hypothesis of this study was analyzed using Paired Sample T-Test. The researcher uses a level of the significance level of 0.05 where the hypothesis is accepted with $a<p$ sign. This means that the probability of error that occurs in the hypothesis is only about $5 \%$. The hypothesis is: 
Ho: there is no significant difference in students' abilities after being taught using animated films.

H1: there is a significant difference in students' abilities after being taught using animated films.

\section{RESULT AND DISCUSSION}

\section{A. Research Result}

To determine the students' initial speaking ability, a pre-test was conducted at the beginning of the study. The following are the results of the pre-test obtained.

TABLE I. THE RESULTS OF THE STUDENTS' PRE-TEST SPEAKING

\begin{tabular}{|c|c|c|}
\hline No & Name & Pre-test Score \\
\hline 1. & $\overline{M A}$ & 70 \\
\hline 2. & $\mathrm{BP}$ & 76 \\
\hline 3. & SA & 79 \\
\hline 4. & JR & 74 \\
\hline 5. & FA & 75 \\
\hline 6. & $\mathrm{AN}$ & 75 \\
\hline 7. & AA & 74 \\
\hline 8. & $\overline{\mathrm{AH}}$ & 74 \\
\hline 9. & RMA & 74 \\
\hline 10 & NB & 72 \\
\hline 11 & $\mathrm{CC}$ & 75 \\
\hline 12 & WPC & 70 \\
\hline 13 & AHR & 70 \\
\hline 14 & KW & 74 \\
\hline 15 & NA & 75 \\
\hline 16 & MA & 80 \\
\hline 17 & DP & 76 \\
\hline 18 & DPL & 72 \\
\hline 19 & SM & 76 \\
\hline 20 & TS & 72 \\
\hline 21 & AS & 77 \\
\hline 22 & RA & 70 \\
\hline 23 & SS & 70 \\
\hline 24 & RA & 77 \\
\hline 25 & $\mathrm{ABP}$ & 75 \\
\hline 26 & ASR & 72 \\
\hline 27 & $\mathrm{DH}$ & 73 \\
\hline 28 & KF & 71 \\
\hline \multicolumn{2}{|c|}{ Average } & 73,86 \\
\hline \multicolumn{2}{|c|}{ Minimum Score } & 70 \\
\hline \multicolumn{2}{|c|}{ Maximum Score } & 80 \\
\hline
\end{tabular}

Based on the table above, it can be seen that the average pre-test score of students is 73.86 . Then, the highest score obtained during the pre-test was 80 and the lowest score obtained was 70 . If you look at these results, actually the average score obtained is quite good. However, this result can still be improved by using animation movies in the speaking learning process.
After knowing the students' initial abilities, animation movies are implemented in class as an effort to improve students' speaking skills. Animation movies are given in class for four meetings. After that, a posttest was conducted to see if there was an increase in students' speaking ability after watching the animation movie. The following are the results of the students' post-test speaking.

TABLE II. THE RESULTS OF THE STUDENTS' POST-TEST SPEAKING

\begin{tabular}{|c|c|c|}
\hline No & Nama & Post-Test Score \\
\hline 1. & MA & 75 \\
\hline 2. & $\mathrm{BP}$ & 78 \\
\hline 3. & SA & 82 \\
\hline 4. & JR & 77 \\
\hline 5. & FA & 79 \\
\hline 6. & AN & 77 \\
\hline 7. & AA & 76,50 \\
\hline 8. & $\mathrm{AH}$ & 76 \\
\hline 9. & RMA & 76,50 \\
\hline 10 & NB & 77 \\
\hline 11 & $\mathrm{CC}$ & 79 \\
\hline 12 & WPC & 77 \\
\hline 13 & AHR & 75 \\
\hline 14 & KW & 78 \\
\hline 15 & NA & 77 \\
\hline 16 & MA & 87 \\
\hline 17 & DP & 79 \\
\hline 18 & DPL & 75 \\
\hline 19 & SM & 76 \\
\hline 20 & TS & 74 \\
\hline 21 & AS & 77 \\
\hline 22 & RA & 74,5 \\
\hline 23 & SS & 73 \\
\hline 24 & RA & 85 \\
\hline 25 & $\mathrm{ABP}$ & 81 \\
\hline 26 & ASR & 73 \\
\hline 27 & DH & 80 \\
\hline 28 & $\mathrm{KF}$ & 74 \\
\hline \multicolumn{2}{|c|}{ Average } & 77,45 \\
\hline \multicolumn{2}{|c|}{ Minimum Score } & 73 \\
\hline \multicolumn{2}{|c|}{ Maximum Score } & 87 \\
\hline
\end{tabular}

The table above shows that the average post-test score of students is 77.45. Then, the highest score obtained at the pre-test was 87 and the lowest score obtained was 73 . If you look at these results, it can be seen that there is an increase in students' speaking skills. However, to see whether the increase was significant or not a T-test was performed. 


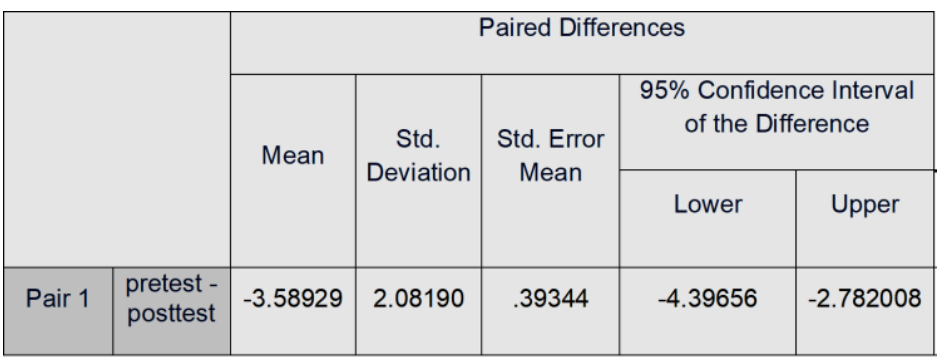

Fig. 1. T-test was performed

The table above shows evidence that there is a significant increase after treatment because (2-tailed) is lower than 0.05 . This shows that the treatment given, animation movies, can significantly improve students' speaking skills.

\section{B. Discussion}

To find out the effect of implementing animation movies on students' speaking ability, there is one question posed in this study, namely, is there a significant increase in students' speaking ability after implementing animation movies? This question is answered by giving treatment to students, namely by implementing animation movies in the learning process. This treatment was carried out for four meetings. After that, a post-test was conducted to see the improvement of students' speaking skills.

After being analyzed, it was found that animation movies had a positive impact because they could significantly improve students' speaking skills. This is because the animated film media can attract students' attention, so students will more easily understand the information conveyed because as many senses as possible are involved, especially the ears and eyes that are used to absorb information. Rahayu and Kristiyantoro (2011) animated films are considered interesting to be used in the learning process so that they can improve the quality of the process and learning outcomes [10].

In addition, according to Sudjana and Rivai (2011:129), audio-visual media are materials that contain messages that can stimulate the thoughts, feelings, attention, and willingness of students, so that the teaching and learning process occurs [6]. By watching animation movies, students are motivated to learn so that during the learning process they are very enthusiastic in following the lesson. Furthermore, their curiosity increased when they watched animation movies.

One of the advantages of animation film compared to other media is that films and videos can accurately describe a process that can be watched repeatedly [12]. Students can understand the material given clearly. By watching animation movies, they have a clear picture of the current situation and situation. This is what helps them in the learning process. In addition, they can also play the video repeatedly when they do not understand the material. So that they understand what is conveyed through the animation video.

Based on the result of the interview it was found that the students gave positive effects after being taught by using animation movies. They realized it was important for them to become confident and self-love, so they could give more appreciation for what people did. Furthermore, students became more optimistic in achieving their dreams because animation movies could give inspiration to them. Therefore, it can be concluded that using animation movies could gave positive impacts on students in the case of character building.

\section{CONCLUSION AND SUGgestion}

The application of animation movies in learning has been proven to significantly improve students' speaking skills. This can be seen from the students' post-test scores obtained after treatment. Animation movies are very helpful for students in understanding learning material because animation movies are interesting, stimulate students' thoughts, feelings, attention, and willingness to learn.

\section{REFERENCES}

[1] Nizzu, D. (2016). IMPROVING STUDENTS SPEAKING SKILLS THROUGH RETELLING STORY BY USING PICTURE SERIES AT SMAN 7 BANDAR LAMPUNG

[2] Rosdiana, R., Boleng, D. T., \& Susilo, S. (2017). Pengaruh penggunaan model discovery learning terhadap efektivitas dan hasil belajar siswa. Jurnal Pendidikan: Teori, Penelitian, dan Pengembangan, 2(8), 1060-1064.

[3] Trisnani, J., Purwanti, O., \& Mustofa, A. (2021). THE USE OF ANIMATED SHORT MOVIE IN TEACHING WRITING NARRATIVE TEXT TO FACILITATE STUDENTS CRITICAL THINKING SKILLS FOR EIGHTH GRADERS. JURNAL EDUCATION AND DEVELOPMENT, 9(1), 319-319.

[4] Diana, N., Khaldun, I., \& Nur, S. (2019). Improving Students' Performance by Using Science Process Skills in The High School's Physics Curriculum Grade X in Indonesia. Jurnal Penelitian \& Pengembangan Pendidikan Fisika, 5(1), 41-48.

[5] Hornby, A.S. (1995). Oxford Advanced Learner's Dictionary of Current Langaunge. Oxford: Oxford University Press.

[6] Sudjana, N.,Rivai. A.(2011). Media Pengajaran dalam Penggunaan dan Pembuatannya. Bandung: Sinar Baru Algensindo.

[7] AH, H. Sanaky. 2009. Media Pembelajaran.

[8] Rinanto, A. (1982). Peranan media audiovisual dalam pendidikan. Yayasan Kanisius. 
[9] Darojah, R. U. (2011). Peningkatan Kemampuan Berbicara Melaporkan Dengan Media Film Animasi Siswa Kelas VIII SMPN 12 Yogyakarta. Skripsi. Yogyakarta: Universitas Negeri Yogyakarta.

[10] Rahayu, T. W. dan A. Kristiyantoro.(2011). Mengoptimalkan Kompetensi Mahasiswa dalam Mata Kuliah Perkembangan Motorik Melalui Media Film Animasi. Jurnal media ilmu keolahragaan Indonesia. 1 (1): 10-16.
[11] Setiyadi, A.B. (2006). Metode Penelitian untuk Pengajaran bahasa Asing Pendekatan Kuantitatif dan Kualitatif. Yogyakarta: Graha Ilmu.

[12] Arsyad, A . (2010). Media Pembelajaran. Jakarta: PT Grafindo Persada. 